Esta publicación cientifica en formato digital es continuidad de la revista impresa ISSN-Versión Impresa 0798-1406 / ISSN-Versión on line 2542-3185Depósito legal pp
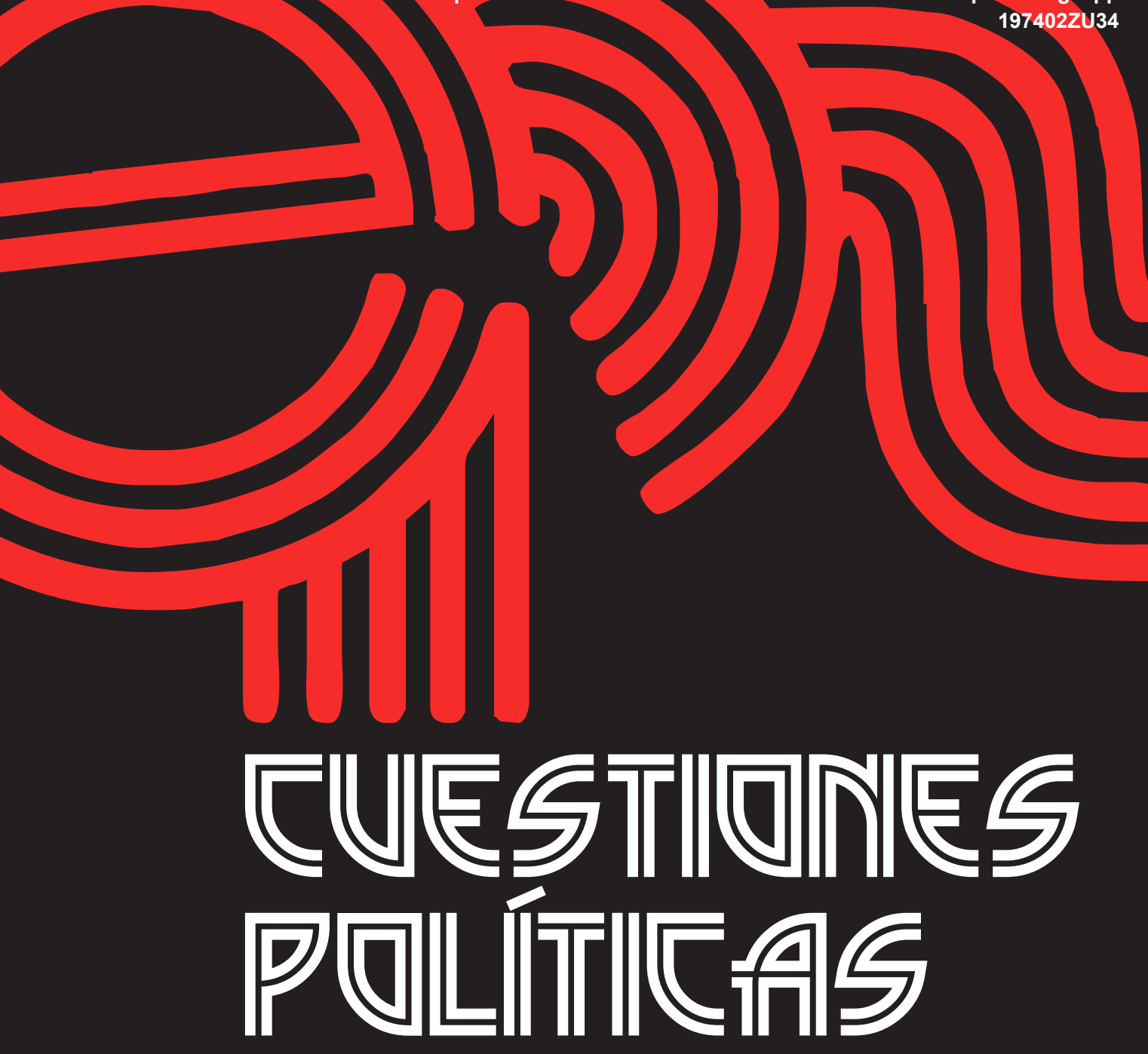

Instituto de Estudios Políticos y Derecho Público "Dr. Humberto J. La Roche" de la Facultad de Ciencias Jurídicas y Políticas de la Universidad del Zulia Maracaibo, Venezuela
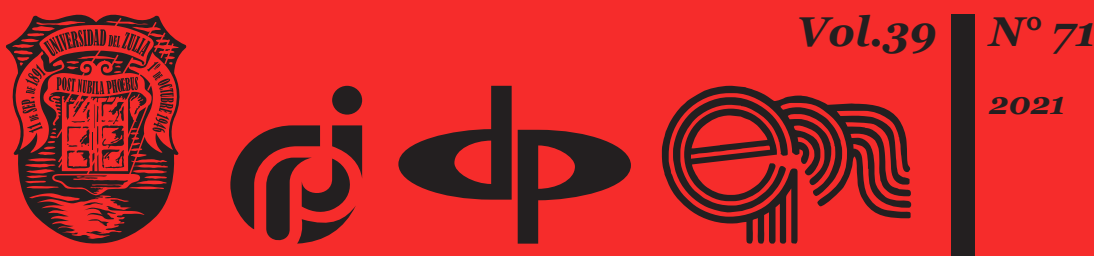


\title{
The transition of insurgent-guerrilla movements to radical terrorist methods of struggle: retrospective features
}

\author{
DOI: https://doi.org/10.46398/cuestpol.3971.50
}

Andrey Ivanovich Baksheev *

Sergey Alekseevich Butorov **

Evgeniya Alekseevna Kurenkova ***

Aleksey Nikolayevich Kuraev ****

Andrey Vyacheslavovich Rybakov *****

\begin{abstract}
The realities of modern reality indicate that there are a significant number of unjustified attempts to resolve controversial issues based on the use of force. The article shows the evolutionary processes of the transition of insurgent-guerrilla movements to radical terrorist methods of struggle in the period of 1991-2001 and reveals the reasons for this process. The article analyzes the definition of "international terrorism" in the modern sense, analyzes the characteristic features of international terrorism of the 1990s, the reasons for its spread, new forms of terrorist activity. The following methods were used in the study of the chosen topic: historical-genetic, comparative-historical; problemchronological, the method of historical modeling. Authors conclude, there is no doubt that all the insurgent-guerilla movements, without exception, pursued their own goals. The most effective way to achieve them at the turn of the century turned out to be precisely terrorist attacks, which, with all the strength of state structures, were not possible to fend off. Thus, terrorism has become a strong weapon in the hands of weak players in the
\end{abstract} international arena.

Keywords: radicalism; terrorism; civil war; guerrilla war; multipolar world.

Professor V.F. Voino-Yasenetsky Krasnoyarsk State Medical University, Krasnoyarsk, Russia. ORCID ID: https://orcid.org/oooo-0oo1-7607-731X

** Russian State University of Tourism and Service, Cherkizovo, Moscow region, Russia. ORCID ID: https://orcid.org/oooo-0oo1-8554-6472

*** Moscow Region State University, Mytischi, Moscow region, Russia. ORCID ID: https://orcid. org/oooo-0oo1-6178-2681

**** K.G. Razumovsky Moscow State University of Technologies and Management (First Cossack University), Moscow, Russia. ORCID ID: https://orcid.org/oooo-0001-7771-3701

***** Moscow Aviation Institute, Moscow, Russia. ORCID ID: https://orcid.org/oooo-0oo2-4909-199X Recibido el 22/09/2021

Aceptado el 22/11/2021 


\section{La transición de los movimientos insurgentes- guerrilleros a métodos de lucha terroristas radicales: características retrospectivas}

\section{Resumen}

Las realidades modernas indican que hay un número significativo de intentos injustificados de resolver cuestiones controvertidas basadas en el uso de la fuerza. El artículo muestra los procesos evolutivos de la transición de los movimientos insurgentes-guerrilleros a métodos de lucha terroristas radicales en el período de 1991-2001 y, al mismo tiempo, revela las razones de este proceso. El artículo analiza la definición de «terrorismo internacional» en el sentido moderno; estudio los rasgos característicos del terrorismo internacional de la década de 1990, las razones de su propagación y las nuevas formas de actividad terrorista. En el estudio del tema elegido se utilizaron los siguientes métodos: históricogenético, comparativo-histórico; problema-cronológico y el método de modelado histórico. Los autores concluyen que no hay duda de que todos los movimientos insurgentes-guerrilleros, sin excepción, persiguieron sus propios objetivos. La forma más efectiva de lograrlos a principios de siglo resultó ser precisamente los ataques terroristas, que, con toda la fuerza de las estructuras estatales, no fueron posibles de evitarse. Por lo tanto, el terrorismo se ha convertido en un arma fuerte en manos de actores débiles en la arena internacional.

Palabras clave: radicalismo; terrorismo; guerra civil; guerra de guerrillas; mundo multipolar.

\section{Introduction}

The modern world continues to live under the pressure of the use of military means in various regions of the world, without which the current post-industrial civilization cannot balance political existence. Battles sometimes break out that are close in intensity to military ones even in the seemingly peaceful politics of many countries.

People often do not feel how fierce political battles imperceptibly draw them into large-scale bloodshed in fratricidal conflicts. We observe armed forms of confrontation today in different regions of the world (Afghanistan, Syria, Mali, Nigeria, Libya, Ethiopia), one of the manifestations of which are armed conflicts in various forms, ranging from minor clashes of paramilitary formations and ending with fairly large-scale hostilities covering the significant territory. As a rule, the causes of these conflicts are the struggle for power within the country, which makes their consequences 
Andrey Ivanovich Baksheev, Sergey Alekseevich Butorov, Evgeniya Alekseevna Kurenkova, Aleksey Nikolayevich Kuraev y Andrey Vyacheslavovich Rybakov

The transition of insurgent-guerrilla movements to radical terrorist methods of struggle: retrospective features

for the population more tangible. In our opinion, local military conflicts today constitute one of the main threats to both national and international security.

According to researchers (Fearon and Laitin, 2003), guerrilla wars (insurgent guerrilla warfare and urban guerrilla warfare) are one of the main forms of civil war, which involves the use of non-conventional strategy methods and allows making long-term campaigns. Carles Boix (2010) emphasizes that such a phenomenon as guerillas is characteristic of civil wars. Moreover, S. Kalyanaraman (2003) believes that the growth in the number of guerillas in some wars suggests that the latter can claim to become an army. According to researchers (Centeno and Hoffman, 2003), insurgent-guerrilla movements occur most often in the poorest countries, rejecting the prospects for the economic and social development of the latter.

The situation with guerrilla movements during the large-scale civil war in Russia in 1918-1922 was no exception. Moreover, the insurgent-guerrilla movements acted both on the side of the Bolsheviks who came to power and fought against the Soviet government.

Moreover, the guerrilla war of the period of the civil war in Russia was distinguished by its scale. In the summer of 1919, the «red guerrillas» of the Altai province, who were on the side of the Soviet government, united in the West Siberian Peasant Red Army, numbering about 25 thousand people. In total, the guerilla movement in Siberia numbered about 100 thousand guerillas, who even before the approach of the Red Army liberated vast areas from the White Guards.

In our opinion, the radical left movements received a new development at the end of the twentieth century. The situation in the world changed dramatically in the early 1990 . The Soviet Union collapsed, and several new states emerged, the traditional religion of which was Islam. The Islamic Republic of Iran continued to be in international isolation, however, without abandoning the «export of the Islamic revolution» to neighboring countries. Libya and Iraq are under international sanctions. Pakistan, on the territory of which the Afghan Mujahideen were located, was forced to intensify its policy towards neighboring Afghanistan, because of which the Najibula regime fell in 1992, and former guerrillas or terrorists came to power.

There were many crises points around the world (Colombia, Mexico, Sri Lanka), where insurgents or terrorists from various organizations were fighting for national liberation, the legal separation of certain territories, or for political power (Smith, 2003). Such zones also appeared on the territory of the former USSR, especially in areas where Muslims mostly lived. 
De facto, the only superpower in the world was the United States, but Washington's policy was ambiguously perceived by most international actors. All this and many other factors not only did not lead to the disappearance of the terrorist threat but on the contrary - to its increase (Smith, 2003). In addition, we should add radical differences between the standard of living in the United States and Western European countries and other countries of the world. Thus, the ground for the development of the international terrorist threat has only increased and today terrorism has acquired an international nature (citizens of different states could be members of terrorist organizations), an international essence (the commission of terrorist attacks was not limited to a particular country, but extended to one or several other states) and the main goal that distinguishes this phenomenon from other forms of struggle is to cause fear among people from heads of state to ordinary residents.

These factors determine the urgency of the problem of studying the causes and peculiarities of the transition of insurgent-guerilla movements to radical terrorist methods of struggle.

The purpose of the study is to analyze the causes and peculiarities of the transition of insurgent-guerilla movements to radical terrorist methods of struggle.

\section{Methods}

The historical and genetic method allowed consistently revealing the origins and development of terrorist forms of the armed struggle of insurgent-guerilla movements to radical terrorist methods of struggle. Using the comparative-historical method, the general and special features of the transition of insurgent-guerilla movements to radical terrorist methods of struggle were shown. Using the problem-chronological method, the corresponding problems that had been existing in the world community during the specified chronological period were identified. The method of historical modeling, or the method of reconstruction, was embodied in the analysis of the reasons for the transition of insurgent-guerilla movements to radical terrorist methods of struggle.

The chronological framework of the study - 1991-2001 - is since it was in the 1990 s that the term «international terrorism» received its usual understanding (the understanding itself, but not the definition). If the term «international terrorism» was used with an ideological meaning in the previous period (during the cold war), now it has acquired its practical meaning. 
Andrey Ivanovich Baksheev, Sergey Alekseevich Butorov, Evgeniya Alekseevna Kurenkova, Aleksey Nikolayevich Kuraev y Andrey Vyacheslavovich Rybakov

The transition of insurgent-guerrilla movements to radical terrorist methods of struggle: retrospective features

\section{Results}

The analysis of literary sources has shown that terrorism can be manifested both by specific actions directed against specific representatives of another state, in fact, up to their physical destruction, and by actions of a military-populist nature.

An example of a concrete manifestation of international terrorism in the 1990 s was the murder by suicide bombers on May 21, 1991, of the Prime Minister of India and the leader of the country's largest Indian National Congress Party, Rajiv Gandhi. None of the organizations claimed responsibility for this action. Much later, the leadership of the insurgent organization Liberation Tigers of Tamil Eelam (LTTE) in Sri Lanka stated that the murder of Rajiv Gandhi was the work of their supporters (Sarvananthan, 2018).

Thus, a terrorist or insurgent organization carried out an act of political murder of the leader of a State on the territory of which it did not conduct its struggle. The consequences of this terrorist attack were beneficial for the LTTE - at the end of the year, Indian troops who helped the Sri Lankan government in the fight against Tamil rebels left the country (Bruevich et al., 2019; Sarvananthan, 2018).

In our opinion, an interesting example of a military-populist action was the uprising of the so-called Zapatista Army of National Liberation in the Mexican state of Chiapas in 1994-1995. This organization, which acted as an insurgent-guerilla formation, but its actions intimidated US citizens on the territory of Mexico, was headed not by an Indian (the Indians were fighters of this army) and not by a Mexican, but most likely by a very educated European who became known to the world under the name of Subcomandante Marcos (Barmeyer, 2003). Moreover, having unexpectedly started the fight, the subordinates of Subcomandante Marcos also unexpectedly stopped it, without winning or losing. Therewith, this army retained all its military structures, which in turn became an indicator of the effectiveness of the so-called latent terrorism, which means intimidation, not by specific terrorist actions, but only by a factor of its existence (Barmeyer, 2003; Zelenkov et al., 2021a, 2021b).

We have concluded that terrorism as a phenomenon, including an international one, has changed dramatically since the previous historical era. In the 1990s, due to several objective reasons, almost all organizations that fought for their interests with the help of weapons turned out to be subjects of international relations in a multipolar world.

This became possible since a kind of regional political vacuum arose because of the collapse of the socialist system, as well as the desire of some countries for a more peaceful policy (for example, India) (Bapat, 2007). 
Armed non-governmental organizations took advantage of it in their struggle. Solely because of this, the Tamil insurgent organization Liberation Tigers of Tamil Eelam was not only able to dramatically increase its potential in the new geopolitical conditions but also to switch to completely new forms of terrorist struggle - on the territory of India and to maritime terrorism. The latter has become a completely new threat, primarily for the South Asian region (Sinai, 2005).

Another characteristic feature of international terrorism in the 1990 s was its activation and radicalization. Moreover, the trend here was twofold. On the one hand, various insurgent-guerrilla organizations, especially in Latin America and Asia, were turning to terrorist forms of struggle (Messelken, 2005). On the other hand, existing terrorist organizations have begun to reorient their activities to the international or even global level. Meanwhile, new organizations began to appear, which were interpreted as terroristic ones with an international orientation. This is against the background of at least the legal refusal of such well-known organizations as the Irish Republican Army and the Palestine Liberation Organization from the terrorist struggle in the early 1990s (Galam, 2003).

Indeed, in Latin America in the early 1990s, everything indicated that Marxist guerrilla groups, finding themselves without material assistance from outside, seeing the collapse of communist ideology and losing their strategic positions due to the effective counteraction of government forces to the rebels, should at best have gone to political negotiations with the government, as happened in 1990-1991 in El Salvador (Consalvi, 2010).

At the end of the 9os, the Colombian insurgents not only did not lay down their weapons but on the contrary switched to new, diverse, including terroristic forms of struggle. As a result, the period of some passivity in 19911997 was replaced by a sharp offensive of Colombian Marxist insurgents on the positions of the government and government troops in 1998-2002. Thereby, two Colombians emerged - official and controlled by Marxists (ORTIZ, 2002). Moreover, the terrorist tactics of the guerrillas of Colombia turned out to be large-scale and effective. As a result, the situation in 19982002 was characterized by a new phenomenon - the terrorist guerrilla (Valenzuela, 2018).

In Peru, Marxist insurgents from the Tupac Amaru Revolutionary Movement, who in 1992 suffered a military defeat together with their colleagues from Sendero Luminoso, were forced to go deep underground. Having partially restored their potential, the Amaru followers did not return to Guerilla but switched purely to terrorist measures (Fumerton, 2018).

On December 17, 1996, 14 fighters of the Tupac Amaru Revolutionary Movement broke into the residence of the Japanese ambassador in Lima, where a gala dinner was organized in honor of the birthday of the Japanese 
Andrey Ivanovich Baksheev, Sergey Alekseevich Butorov, Evgeniya Alekseevna Kurenkova, Aleksey Nikolayevich Kuraev y Andrey Vyacheslavovich Rybakov

The transition of insurgent-guerrilla movements to radical terrorist methods of struggle: retrospective features

Emperor Akihito. Immediately, more than 500 guests and members of the embassy were taken hostage. The terrorist insurgents demanded the release of more than 400 of their associates from prison. However, this could lead to the fact that all the efforts of the government of Peruvian President Alberto Fujimori to fight left-wing insurgents would be in vain. That is why the international crisis had to be solved radically. On April 23, 1997, special forces units of the Peruvian army stormed the Japanese Embassy in Lima. The terrorists were killed, but some of the hostages also died (Tolmacheva et al., 2018; Zirakzadeh, 2002).

An active process of transferring the terrorist activity of existing nongovernmental organizations to the international level began in 19912001. Moreover, this phenomenon remains unclear until now, since the actual initiators of this process are almost unknown. Most likely, the first manifestation can be considered the explosion of the Israeli embassy in Buenos Aires on March 17, 1992. Then 29 people were killed, and about 250 were seriously injured. According to the first versions, the initiators of this terrorist attack could be either «Nazi groups» or «Marxist insurgents». A specially created commission to investigate this terrorist attack did not come to a consensus. However, the President of Argentina, Carlos Menem, blamed the «Islamic radicals» for this terrorist attack (Zirakzadeh, 2002).

That is why we concluded that international terrorism has received an «Islamic» coloring. In our opinion, the reason for such a widespread opinion, even among scholars, is several factors.

Firstly, the authors of almost all large-scale terrorist acts are still unknown. They are unknown because they have not been captured by the law enforcement agencies of the countries where the terrorist attacks were committed. Namely, this does not give grounds for any accusations.

Secondly, the radicalization of the Islamic world took place. Thus, almost all the countries of North Africa were threatened by Islamic radical organizations (Hinds, 2013). In Algeria, since 1992, Islamic radicals have launched a civil war. In Egypt, it was terrorists from radical Islamic groups who organized large-scale terrorist attacks against foreigners several times (the explosion of a bus with German tourists in Sharm el-Sheikh in 1997, the assassination attempt on Egyptian President Hosni Mubarak in Sudan in 1998). All this has led to the fact that it was Egypt that began to use extremely radical methods to fight against Islamic radicals and international terrorism. These measures proved to be very effective, but they did not find understanding among the politicians of the states of the region (Hinds, 2013).

Thirdly, the consequences of the Afghan war of 1979-1989 manifested themselves. In its course, the United States was forced to rely on nonstandard measures of struggle in the confrontation with the USSR for 
Afghanistan. These measures were taken by mercenaries from Arab or Islamic countries who fought against the Soviet troops on the side of the guerrillas-mujahideen.

Each of them received a salary of at least 1,500 USD dollars per month and therefore was interested in this source of profit. That is why such mercenaries had been fighting for years (Grau, 2018). However, after 1992, when the Taliban Mujahideen seized power in Afghanistan, the war theoretically ended. Due to this, the former «fighters for the faith» began to return to their countries, where they could not integrate into peaceful life and turned out to be a destabilizing factor in the internal life of their countries, as they joined the ranks of radical anti-government organizations (Guest, 2010).

Pakistan has had a particularly difficult time in this regard. On the one hand, this country was an outpost of the struggle against the USSR in Afghanistan, since the camps of the Afghan mujahideen were located on the territory of the Islamic Republic, where Arab mercenaries were trained. On the other hand, a significant number of radical-minded people and wellarmed ones have appeared in the country (according to experts, more than 1 million Kalashnikov assault rifles are in the hands of radicals in Pakistan - twice as many as in the entire Pakistani army) (Guest, 2010).

This is what led to the fact that Pakistani society did not follow the path of Islamic radicalization. In this case, the only measure, according to the researchers (Findley and Young, 2012), was the attempt of the Pakistani government not so much to fight the radicals but to send them out of the country. As a result, international terrorism was de facto provided with personnel.

Another significant factor in the transition of insurgent-guerilla movements to radical terrorist methods of struggle was the fact that terrorism turned out to be financially accessible to many. Thus, according to researchers (Carter, 2016), terrorist acts do not require large funds and cost an average of 10-30 thousand dollars. Moreover, many of the previously existing insurgent-guerrilla movements accumulated significant finances, for example, from drug trafficking, obtaining ransom for hostage-taking, and the like (Carter, 2016; Gurinovich and Petrykina, 2021).

Thus, there were political, ideological, personnel, and material conditions for the reformatting of insurgent-guerrilla movements into international terrorist organizations. It should be noted that the main activity of international terrorist groups has become the struggle against any hegemony, and in the case of Islamic organizations, the creation of a hypothetical Islamic state. However, this idea turned out to be flawed precisely because Muslims themselves are different and only the most radical of them could support it. In addition, the idea of «political Islam» 
Andrey Ivanovich Baksheev, Sergey Alekseevich Butorov, Evgeniya Alekseevna Kurenkova, Aleksey Nikolayevich Kuraev y Andrey Vyacheslavovich Rybakov

830

The transition of insurgent-guerrilla movements to radical terrorist methods of struggle: retrospective features

- that is, the spread of the influence of the Islamic religion in the world turned out to be unfavorable in the West, which once again equated even moderate Islamists with terrorists.

\section{Conclusion}

Thus, terrorism as a social phenomenon has turned into an international problem in the conditions of the world's transition from bipolar to multipolar. This was made possible due to the virtually imperial policy on the part of the United States, the radicalization of societies in countries, primarily Asia and Latin America, the accumulation of significant material resources among some of the insurgent-guerilla movements, and, most importantly, the emergence of an international political situation in which terrorist organizations were able to fill the international vacuum that arose because of the end of the cold war.

The extraordinary effectiveness of the terrorist attacks was revealed very quickly, which in turn prompted the terrorists to spread their actions to an almost global level. This, in turn, prompted the rapprochement and even the unification of terrorist organizations into single international structures. However, the idea of creating a Worldwide caliphate itself turned out to be very abstract, and if so, it became a psychological weapon of international terrorism, which, if not frightened the governments of the leading countries of the world, then forced them to take the terrorist threat seriously.

\section{Bibliographic References}

BAPAT, Navin A. 2007. "The internationalization of terrorist campaigns" In: Conflict Management and Peace Science. Vol. 24, No. 4, pp. 265-280.

BARMEYER, Niels. 2003. "The guerrilla movement as a project: an assessment of community involvement in the EZLN" In: Latin American Perspectives. Vol. 30, No. 1, pp. 122-138

BOIX, Carles. 2010. "Civil wars and guerrilla warfare in the contemporary world: toward a joint theory of motivations and opportunities" In: Order, conflict, and violence. Eds. S.N. Kalyvas, I. Shapiro and T.M. Order. Cambridge University Press. Cambridge, UK. Pp. 197-218

BRUEVICH, Marina Yurievna; GUBANOVA, Olga Aleksandrovna; LEINOVA, Olga Sergeevna; TSECHOEV, Kharon Isaevich; SITKOVA, Karina Evgenevna. 2019. "The use of special knowledge in the investigation of terrorism-related crimes" In: Amazonia Investiga. Vol. 8, No. 21, pp. 707-711. 
CENTENO, Miguel; HOFFMAN, Kelly. 2003. "The lopsided continent: inequality in Latin America” In: Annual Review of Sociology. Vol. 29, pp. 363-390.

CONSALVI, Carlos Henriquez. 2010. Broadcasting the civil war in El Salvador: a memoir of guerrilla radio. University of Texas Press. Austin, TX. 293 p.

CARTER David, B. 2016. "Provocation and the strategy of terrorist and guerrilla attacks” In: International Organization. Vol. 70, No. 1, pp. 133-173.

FEARON, James D; LAITIN, David. 2003. "Ethnicity, insurgency, and civil war" In: American Political Science Review. Vol. 97, pp. 75-90.

FINDLEY, Michael G; YOUNG, Joseph K. 2012. "Terrorism and civil war: a spatial and temporal approach to a conceptual problem" In: Perspectives on Politics. Vol. 10, No. 2, pp. 285-305.

FUMERTON, Mario Antonio. 2018. "Beyond counterinsurgency: peasant militias and wartime social order in Peru's civil war" In: European Review of Latin American and Caribbean Studies. Vol. 105, pp. 61-86.

GALAM, Serge. 2003. "Global physics: from percolation to terrorism, guerilla warfare and clandestine activities" In: Physica A. Vol. 330, pp. 139-149.

GUEST, Ken. 2010. "Dynamic interplay between religion and armed conflict in Afghanistan" In: International Review of the Red Cross. Vol. 92, No. 880, pp. 877-897.

GURINOVICH, Aleksandr G.; PETRYKINA, Natalia I. 2021. "Specifics of developing the institution of public service: international experience and its application in Russia” In: Juridicas Cuc. Vol. 17, No. 1, pp. 253-276.

HINDS, Rosin. 2013. Islamic radicalisation in North and West Africa: drivers and approaches to tackle radicalization. (Rapid Literature Review). GSDRC, University of Birmingham. Birmingham, UK. 16 p.

KALYANARAMAN, S. 2003. "Conceptualisations of guerrilla warfare" In: Strategic Analysis. Vol. 27, No. 2, pp. 172-185.

GRAU, Lester W. 2018. "Defeating guerrilla logistics: Soviet operation 'Trap' in Western Afghanistan” In: Journal of Slavic Military Studies. Vol. 31, No. 1, pp. 65-79.

MESSELKEN, Daniel. 2005. "Terrorism and guerrilla warfare - a comparative essay" In: Ethics of terrorism and counter-terrorism. Ethics of terrorism and counter-terrorism. Ed. G. Meggle. Ontos Verlag. Heusenstamm. Berlin, Germany, pp. 51-68. 
Andrey Ivanovich Baksheev, Sergey Alekseevich Butorov, Evgeniya Alekseevna Kurenkova, Aleksey Nikolayevich Kuraev y Andrey Vyacheslavovich Rybakov

The transition of insurgent-guerrilla movements to radical terrorist methods of struggle: retrospective features

ORTIZ, Roman. 2002. "Insurgent strategies in the post-cold war: the case of the revolutionary armed forces of Colombia" In: Studies in Conflict and Terrorism. Vol. 25, No. 2, pp. 127-143.

SARVANANTHAN, Muttukrishna. 2018. "Terrorism or liberation? Towards a distinction: a case study of the armed struggle of the Liberation Tigers of Tamil Eelam (LTTE)" In: Perspectives on Terrorism. Vol. 12, No. 2, pp. 1-18.

SINAI, D. 2005. "Tendentsii mirovogo morskogo terrorizma [Trends in global maritime terrorism]" In: Aziya i Afrika segodnya. No. 7, pp. 42-43.

SMITH, M.L.R. 2003. "Guerrillas in the mist: reassessing strategy and lowintensity warfare" In: Review of International Studies. Vol. 29, pp. 19-37.

TOLMACHEVA, Svetlana Vladimirovna; RESHETNIKOVA, Irina Gennadijevna; STASHKOVSKAYA, Natalia Vladimirovna; MELNIK, Vladimir Vladimirovich; SAMOYLOVA, Yana Victorovna. 2018. "The influence of the islamic factor on the formation of religious identity" In: European Journal of Science and Theology. Vol. 14, No. 6, pp. 77-86.

VALENZUELA, Pedro. 2018. "The end of the armed conflict in Colombia: a multiple causal factor explanation" In: Peace and Change. Vol. 43, No. 2, pp. 205-217.

ZELENKOV, Mikahail Yuryevich; FEDYAKIN, Ivan Vladimirovich; ZINKOVSKY, Sergey Borisovich; NIKITINA, Valentina Sergeevna; BIKOV, Mikhail Yrievich. 2021a. "Religion-state relations as a source of modern” In: Laplage Em Revista. Vol. 7, No. 2, pp. 463-472.

ZELENKOV, Mikahail Yuryevich; LAAMARTI, Yulia Alekseevna; ZINKOVSKY, Sergey Borisovich; SHERMUKHAMEDOVA, Nigina; DIAGHILEV, Vasily Vasilievich; VASILYEVA, Oksana Nikolaevna. 2021b. "The system of key risk factors contributing to religious terrorist activities in the 21st century" In: European Journal of Science and Theology. Vol. 17, No. 3, pp. 91-101.

ZIRAKZADEH, Cyrus Ernesto. 2002. "From revolutionary dreams to organizational fragmentation: disputes over violence within ETA and Sendero Luminoso" In: Terrorism and Political Violence. Vol. 14, No. 4, pp. 66-92. 

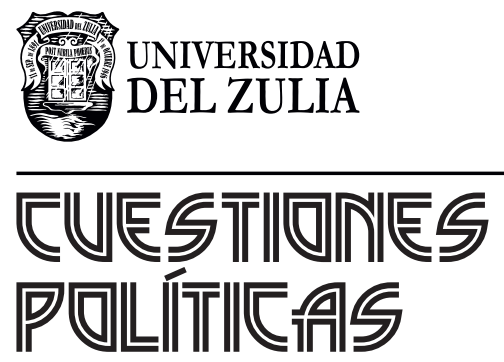

Vol. 39 N $^{\circ} 71$

Esta revista fue editada en formato digital y publicada en diciembre de 2021, por el Fondo Editorial Serbiluz, Universidad del Zulia. Maracaibo-Venezuela 